\title{
Diagnoses and factors associated with medical evacuation and return to duty among nonmilitary personnel participating in military operations in Iraq and Afghanistan
}

\author{
Steven P. Cohen MD, Charlie Brown MD, Connie Kurihara RN, Anthony Plunkett MD, Conner Nguyen MD,
} Scott A. Strassels PharmD PhD

\begin{abstract}
Background: Nonmilitary personnel play an increasingly critical role in modern wars. Stark differences exist between the demographic characteristics, training and missions of military and nonmilitary members. We examined the differences in types of injury and rates of returning to duty among nonmilitary and military personnel participating in military operations in Iraq and Afghanistan.
\end{abstract}

Methods: We collected data for nonmilitary personnel medically evacuated from military operations in Iraq and Afghanistan between 2004 and 2007. We compared injury categories and return-to-duty rates in this group with previously published data for military personnel and identified factors associated with return to duty.

Results: Of the 2155 medically evacuated nonmilitary personnel, $74.7 \%$ did not return to duty. War-related injuries in this group accounted for $25.6 \%$ of the evacuations, the most common causes being combat-related injuries (55.4\%) and musculoskeletal/spinal injuries (22.9\%). Among individuals with nonwar-related injuries, musculoskeletal injuries accounted for $17.8 \%$ of evacuations. Diagnoses associated with the highest return-to-duty rates in the group of nonmilitary personnel were psychiatric diagnoses (15.6\%) among those with war-related injuries and noncardiac chest or abdominal pain $(44.0 \%)$ among those with non-war-related injuries. Compared with military personnel, nonmilitary personnel with war-related injuries were less likely to return to duty $(4.4 \%$ v. $5.9 \%, p=0.001)$ but more likely to return to duty after non-war-related injuries (32.5\% v. 30.7\%, $p=0.001$ ).

Interpretation: Compared with military personnel, nonmilitary personnel were more likely to be evacuated with non-war-related injuries but more likely to return to duty after such injuries. For evacuations because of warrelated injuries, this trend was reversed.

I $\mathrm{n}$ modern warfare, injuries sustained in combat have never been the leading source of attrition among soldiers. In World War I, World War II and the Korean War, respiratory and infectious diseases were the top reasons for hospital admissions among service members. By the Vietnam Conflict, non-battle injuries had supplanted respiratory illness as the leading cause of hospital admissions and have remained the leading cause ever since. ${ }^{1,2}$

The principal causes for medical evacuation of military personnel from US operations in Iraq and Afghanistan were recently described in a large four-year epidemiologic study. ${ }^{3}$ In de scending order, the leading reasons were musculoskeletal conditions, combat-related injuries, neurologic symptoms and psychiatric disorders; the last category surpassed combat-related in -

juries as the number two reason in the latter half of both engagements. However, nonmilitary personnel were not included in that study. Over the past three years, nonmilitary members, including US Department of Defense civilians, private contractors and diplomats, have comprised about $50 \%$ of personnel serving in Iraq and about twothirds of those serving in Afghanistan., ${ }^{4.5}$

Several reasons may explain why the types of injury and the return-to-duty rates differ between military and nonmilitary personnel. First, the motivations for overseas deployment might differ between the groups. Whereas some civilian personnel (e.g., diplomats) may be assigned to positions in Iraq and Afghanistan, virtually all private contractors volunteer for their jobs. In contrast, most military members have little choice in their deployment. Second, military and
Competing interests:

Steven Cohen was paid for expert testimony in a lawsuit defending the US Department of Defense and has received speaker fees for a presentation at the Hong Kong Orthopedic Association 2010 annual meeting. No competing interests declared by the other authors.

This article has been peer reviewed.

Correspondence to: Dr. Steven P. Cohen, scohen40@jhmi.edu

CMAJ 2011. DOI:10.1503 /cmaj.100244 
nonmilitary members assigned to war zones have different occupational specialties, living conditions and regulations to which they must adhere. Especially for junior military personnel, jobs tend to be more dangerous, living environments more austere and regulations more stringent. Finally, unlike military personnel, who are paid regardless of deployment status, most contractors' pay is contingent upon continued employment in theatres of operation. In addition, nonmilitary personnel are generally compensated with higher salaries than service members in comparable occupational specialties.

In civilian cohorts, many of these factors have been shown to influence return-to-work rates in a variety of contexts. Studies of the effect of financial compensation on work status after injury have generally shown a direct correlation between return-to-work rates and higher income levels. ${ }^{6,7}$ Similar associations have also been found between return-to-work rates and job satisfaction and coping mechanisms, factors that may be influenced by work conditions and perceived control over one's environment. . $^{8-10}$

The objectives of our study were threefold: to ascertain whether the reasons for medical evacuation from military operations differed between military and nonmilitary personnel; to determine whether return-to-duty rates differed between the two groups; and to identify factors that influence return-to-duty rates among nonmilitary members.

\section{Methods}

\section{Patients and data source}

Permission to conduct this study was granted by the Human Use Committee at Walter Reed Army Medical Center. A list of nonmilitary personnel medically evacuated from forwarddeployed units involved in US operations in Iraq (Operation Iraqi Freedom) and Afghanistan (Operation Enduring Freedom) between 2004 and 2007 was obtained from a database actively maintained in Landstuhl, Germany, by the Deployed Warrior Medical Management Center. This centre was instituted in November 2002 to facilitate the coordination of medical evacuations from forward-deployed areas to Ramstein Air Base in Germany, and to optimize patient management. This database contains demographic and clinical information on more than $98 \%$ of evacuated US Department of Defense beneficiaries (e.g., civilians, retired and reserve military contractors, and service members). Others sometimes included in this database are members of non-US military coalition forces, private and government contractors, members of US and foreign State Department and intelligence services,
United Nations employees and others (e.g., journalists and visitors). Data for the comparison group of military personnel were obtained from a previously published study that was conducted using the same database. ${ }^{3}$

For members who are not US Department of Defense beneficiaries, care in forward-deployed areas is free and available at the fourth level treatment centre in Landstuhl, Germany, on a "space available" basis. Foreign military medical support is a national responsibility outside of theatre and is governed by nation-to-nation agreements. Hence, for our study, the most valid means to calculate risk estimates among nonmilitary personnel was to use data for US Department of Defense civilians, who use the same evacuation and treatment schemata as military personnel. We categorized individuals as Department of Defense personnel using data from the Defense Manpower Data Center, information from individual patient records and data from the Deployed Warrior Medical Management Center database. The number of Department of Defense civilians serving in overseas military operations for each month of the study was obtained from the US Central Command Joint Personnel Status and Casualty Report section, MacDill Air Force Base, Florida.

\section{Diagnoses and outcome measures}

All diagnoses were conferred by the treating physician in the theatre of operation based on the primary reason for medical care. Classification into disease categories was based on the International Classification of Diseases, 9th revision, Clinical Modification (ICD-9-CM) codes for diseases and injuries. Although exceptions are made for severe injuries and extenuating circumstances, most evacuated personnel remain in the Deployed Warrior Medical Management Center for up to two weeks before a final decision is made on disposition. In addition to diagnosis and disposition, data on the individual's age, sex and whether or not the injury was incurred during operational missions are prospectively recorded.

Injuries were categorized into two groups: war-related injuries, and non-war-related injuries and disease. War-related injuries comprised all diagnoses of combat-related, psychiatric and traumatic brain injuries, as well as injuries in other categories (e.g., musculoskeletal/spine) that were sustained during operational missions. Combatrelated injuries were defined as injuries sustained as a result of enemy action. To illustrate the distinction, a contractor who herniates a disc during an operational transport mission would have the injury categorized as "war-related musculoskeletal/spine injury," not a combat-related injury. A 
preliminary review of more than 3000 medical records revealed a diagnostic coding error of less than $1 \%$.

The categorical outcome measure, return to duty, was considered positive if the individual returned to theatre in full or limited capacity. For personnel medically evacuated to the United States or their home country, the outcome was designated as negative.

\section{Statistical analysis}

Clinical and demographic characteristics were assessed, with mean and standard deviation for age, and counts and proportions for categorical variables. We assessed statistical significance using the $t$ test with unequal variances for age, and Pearson $\chi^{2}$ and Fisher exact tests for categorical variables. To estimate the association between return to duty and demographic or clinical characteristics, we constructed a multivariable logistic regression model, with odds ratios adjusted for age, sex, military status, and whether or not the injury was war related. All variables in the multivariable models were included simultaneously and retained, regardless of statistical significance.

\section{Results}

The demographic characteristics of the 2155 evacuated nonmilitary personnel are shown in Table 1. These individuals had a mean age of 44.4 years (standard deviation [SD] 11.5), and 91.0\% were male. Almost half (49.7\%) were private contractors; the remainder were US Department of Defense civilians (29.2\%), United Nations and other US or foreign government personnel (e.g., State Department or Intelligence Services; $3.9 \%$ ), and others (e.g., journalists, visitors; $17.2 \%$ ). Non-war-related injuries accounted for $74.4 \%$ of evacuations, and $74.7 \%$ of individuals did not return to duty. Based on the mean number of Department of Defense civilians serving in overseas military operations on a monthly basis (3978.2 [SD 554.3]) and the number of evacuees, the evacuation rate for this population was 4.5 individuals per 1000 person-months. Because these data do not include individuals on temporary assignments, this rate may slightly overestimate the risk.

The most prevalent diagnoses among nonmilitary personnel were musculoskeletal/spine injuries (19.1\%), combat injuries (14.2\%) and circulatory disorders (12.6\%). Among military personnel who were evacuated, the most common injuries were musculoskeletal/spine disorders $(30.8 \%)$, combat-related injuries $(13.9 \%)$ and psychiatric diagnoses $(9.1 \%)$.
The greatest differences in diagnoses between nonmilitary and military personnel were for psychiatric diagnoses $(2.1 \%$ v. $9.1 \%, p<0.001)$, circulatory conditions $(12.6 \%$ v. $4.4 \%, p<0.001)$, noncardiac chest or abdominal pain $(11.2 \% \mathrm{v}$. $3.7 \%, p<0.001)$ and non-war-related musculoskeletal/spine disorders $(13.3 \%$ v. $24.4 \%, p<$ 0.001 ). Among nonmilitary individuals evacuated because of a psychiatric condition, $36.4 \%$ had a stress reaction, $29.6 \%$ a mood disorder and $13.6 \%$ a substance abuse problem.

Among the nonmilitary personnel who were evacuated, $95.6 \%$ of those with a war-related injury and $67.5 \%$ of those with a non-warrelated injury did not return to duty (Table 2). Among those with a war-related injury, the return-to-duty rate was lowest for those with a combat-related injury $(3.0 \%)$ or a musculoskeletal/spine injury (3.2\%). Among nonmilitary per-

Table 1: Baseline characteristics of 36160 nonmilitary and military personnel evacuated from military operations in Iraq and Afghanistan between 2004 and 2007

\begin{tabular}{|c|c|c|c|}
\hline \multirow[b]{2}{*}{ Characteristic } & \multicolumn{2}{|c|}{ Group; no. (\%) of evacuees* } & \multirow[b]{2}{*}{$p$ value } \\
\hline & $\begin{array}{c}\text { Nonmilitary } \\
\text { personnel } \\
n=2155\end{array}$ & $\begin{array}{c}\text { Military } \\
\text { personnel } \\
n=34005 t\end{array}$ & \\
\hline Age, yr, mean (SD) & $44.4(11.5)$ & $29.8 \quad(9.1)$ & $<0.001$ \\
\hline \multicolumn{3}{|l|}{ Sex } & 0.001 \\
\hline Male & $1961(91.0)$ & \multicolumn{2}{|l|}{$30182(88.8)$} \\
\hline Female & $194 \quad(9.0)$ & \multicolumn{2}{|l|}{$3822(11.2)$} \\
\hline War-related injury & $551(25.6)$ & 11108 (32.7) & $<0.001$ \\
\hline Combat-related $\ddagger \S$ & $305(14.2)$ & $4713(13.9)$ & 0.70 \\
\hline Psychiatric§ & $45 \quad(2.1)$ & $3108 \quad(9.1)$ & $<0.001$ \\
\hline Traumatic brain injury§ & $52 \quad(2.4)$ & $555 \quad(1.6)$ & 0.006 \\
\hline Musculoskeletal/spine** & $126(5.8)$ & 2175 (6.4) & 0.31 \\
\hline Other** & $23(1.1)$ & $557 \quad(1.6)$ & 0.041 \\
\hline $\begin{array}{l}\text { Non-war-related injury } \\
\text { or disease }\end{array}$ & $1604(74.4)$ & $22897(67.3)$ & $<0.001$ \\
\hline Circulatory & $271(12.6)$ & 1500 & $<0.001$ \\
\hline $\begin{array}{l}\text { Noncardiac chest or } \\
\text { abdominal pain }\end{array}$ & $241(11.2)$ & 1242 & $<0.001$ \\
\hline Gastrointestinal & $203 \quad(9.4)$ & $2395 \quad(7.0)$ & $<0.001$ \\
\hline Musculoskeletal/spine & $286(13.3)$ & $8306(24.4)$ & $<0.001$ \\
\hline Other & $603(28.0)$ & $9454(27.8)$ & 0.86 \\
\hline \multicolumn{2}{|l|}{ Returned to duty } & & 0.003 \\
\hline No & 1609 (74.7) & \multicolumn{2}{|l|}{$26330(77.4)$} \\
\hline Yes & $546(25.3)$ & \multicolumn{2}{|l|}{7675 (22.6) } \\
\hline \multicolumn{4}{|c|}{$\begin{array}{l}\text { Note: SD = standard deviation. } \\
\text { *Unless stated otherwise. } \\
\text { tData are from Cohen et al. } \\
\text { fCombat-related injuries were those that resulted from direct enemy actions. } \\
\text { §All combat-related injuries, psychiatric diagnoses and traumatic brain injuries were } \\
\text { considered to be war-related. } \\
\text { **Includes only injuries designated to have occurred during combat operations. }\end{array}$} \\
\hline
\end{tabular}


sonnel with a non-war-related injury, those with a circulatory condition $(26.2 \%)$ or a musculoskeletal/spine injury (22.4\%) were least likely to return to duty.

Table 3 compares the proportion of nonmilitary and military personnel who returned to duty stratified by diagnosis. Most of the nonmilitary personnel $(56.0 \%-97.1 \%)$ did not return to duty regardless of diagnosis. The disease categories with the highest return-to-duty rates were noncardiac chest or abdominal pain (44.0\%) and gastrointestinal disorders (35.5\%). Overall, $15.6 \%$ of nonmilitary members with psychiatric diagnoses returned to duty, although the number of affected individuals was small $(n=7)$. Among the nonmilitary members evacuated because of a psychiatric diagnosis, the highest return-to-duty rates were noted among those with a substance abuse problem or "other" condition (e.g., personality disorder, schizophrenia).

Among the military personnel, return-to-duty rates were highest among those with a diagnosis of noncardiac chest or abdominal pain (51.9\%)

Table 2: Characteristics of evacuated nonmilitary personnel according to whether they returned to duty

\begin{tabular}{|c|c|c|c|}
\hline \multirow[b]{2}{*}{ Characteristic } & \multicolumn{2}{|c|}{$\begin{array}{c}\text { Outcome; no. (\%) of evacuated } \\
\text { nonmilitary personnel* }\end{array}$} & \multirow[b]{2}{*}{$p$ value } \\
\hline & $\begin{array}{l}\text { Did not return } \\
\text { to duty } \\
n=1609\end{array}$ & $\begin{array}{l}\text { Returned } \\
\text { to duty } \\
n=546\end{array}$ & \\
\hline Age, yr, mean (SD) & $44.0(11.8)$ & $45.5(10.7)$ & 0.015 \\
\hline \multicolumn{3}{|l|}{ Sex } & \multirow[t]{2}{*}{$<0.001$} \\
\hline Male & $1493(76.1)$ & \multirow{2}{*}{\multicolumn{2}{|c|}{$78(40.2)$}} \\
\hline Female & $116(59.8)$ & & \\
\hline War-related injury & $527(95.6)$ & $24 \quad(4.4)$ & 0.002 \\
\hline Combat-related†‡ & $296(97.1)$ & $9 \quad(3.0)$ & $<0.001$ \\
\hline Psychiatric $\neq$ & $38(84.4)$ & 7 (15.6) & 0.13 \\
\hline Traumatic brain injury & $50(96.2)$ & $2 \quad(3.9)$ & $<0.00$ \\
\hline Musculoskeletal/spine§ & $122(96.8)$ & $4 \quad(3.2)$ & $<0.001$ \\
\hline Other§ & $21(91.3)$ & $2(8.7)$ & 0.06 \\
\hline $\begin{array}{l}\text { Non-war-related injury } \\
\text { or disease }\end{array}$ & $1082(67.5)$ & $522(32.5)$ & $<0.001$ \\
\hline Circulatory & $200(73.8)$ & $71(26.2)$ & 0.73 \\
\hline $\begin{array}{l}\text { Noncardiac chest or } \\
\text { abdominal pain }\end{array}$ & $135(56.0)$ & $106(44.0)$ & $<0.001$ \\
\hline Gastrointestinal & $131(64.5)$ & $72(35.5)$ & $<0.001$ \\
\hline Musculoskeletal/spine & $222(77.6)$ & $64(22.4)$ & 0.22 \\
\hline Other & $394(65.3)$ & $209(38.3)$ & $<0.001$ \\
\hline \multicolumn{4}{|c|}{$\begin{array}{l}\text { Note: SD = standard deviation. } \\
\text { *Unless stated otherwise. Percentages are based on row totals. } \\
\text { tCombat-related injuries were those that resulted from direct enemy actions. } \\
\text { fAll combat-related injuries, psychiatric diagnoses and traumatic brain injuries were } \\
\text { considered to be war-related. } \\
\text { SIncludes only injuries designated to have occurred during combat operations. }\end{array}$} \\
\hline
\end{tabular}

or a gastrointestinal condition (48.6\%). For warrelated conditions, only $9.2 \%$ of military personnel with a psychiatric diagnosis and $3.3 \%$ with a musculoskeletal/spine disorder returned to duty.

Statistically significant differences in return-toduty rates between nonmilitary and military personnel were found among those with psychiatric diagnoses $(15.6 \%$ v. $9.2 \%, p=0.003)$ and among those with non-war-related circulatory conditions $(26.2 \%$ v. $39.1 \%, p<0.001)$, noncardiac chest or abdominal pain $(44.0 \%$ v. $51.9 \%, p<0.001)$ and musculoskeletal/spine disorders (22.4\% v. $15.9 \%$, $p=0.001)$. Overall, for war-related injuries, return-to-duty rates were higher among military personnel than nonmilitary personnel; for nonwar-related injuries, return-to-duty rates were higher among nonmilitary members.

Estimates of the association between returnto-duty rates and demographic and clinical characteristics are shown in Table 4. In the multivariable analyses, military status and war-related injuries were significantly associated with return-to-duty rates, albeit in different directions. Specifically, individuals with a war-related injury were $83 \%$ less likely to return to duty, and military personnel were $19 \%$ more likely to return to duty.

Twenty nonmilitary patients died within two years after evacuation, 18 within the first year. Seven of these patients were evacuated because of a gastrointestinal disorder, two patients each were evacuated because of circulatory, neurologic, blood and congenital anomalies, and one patient each was evacuated because of spine injury, psychiatric disorder, infectious disease, noncardiac chest pain and neoplasm.

\section{Interpretation}

Overall, the reasons for medical evacuation were comparable between the military and nonmilitary personnel, although we noted several important differences. The observation that military personnel were more likely to be evacuated with war-related injuries, and nonmilitary members with non-war-related injuries, was not unexpected. What was surprising was that the principal contributor to this disparity was the higher evacuation rates among military personnel than among nonmilitary personnel because of psychiatric diagnoses $(9.1 \%$ v. $2.1 \%)$. This effect was amplified by the fact that military personnel were less likely than nonmilitary members to return to duty after evacuation because of a psychiatric condition.

The other major finding was the higher toll that circulatory conditions and noncardiac chest or abdominal pain exacted on nonmilitary mem- 
bers. In contrast, military personnel evacuated with non-war-related injuries were more likely to have a diagnosis related to musculoskeletal/ spine disorders. These effects were again magnified by the differences in return-to-duty rates between the two groups.

The similarities in the types of war-related and non-war-related injuries between the military and nonmilitary groups may be explained in part by the overlap between the missions and duties of each cohort. Compared with previous conflicts, nonmilitary personnel serving in Iraq and Afghanistan have assumed many of the responsibilities once reserved for military personnel, such as transport missions. They are therefore subjected to a similar array of psychophysical stressors and may consequently experience similar injury patterns. Yet, certain differences between the cohorts did emerge. Military personnel had a significantly higher proportion of musculoskeletal injuries, especially nonwar-related injuries, than nonmilitary members did. Since statistics have been kept, orthopedic injuries have been the leading cause of unit declension (e.g., medical evacuation, hospital admission, death, visit to medical providers), both in theatre and in garrison. ${ }^{11,12}$ Also, nonmilitary members were more likely than military personnel to return to duty after a musculoskeletal injury, which may reflect differences in injury severity and mission requirements. Whereas contractors are often exposed to combat hazards and musculoskeletal stressors in the line of duty, the physical requirements needed to perform these duties may be less rigorous than those of military personnel performing reconnaissance and counterinsurgency missions who are carrying equipment that often weighs more than $30 \mathrm{~kg} \cdot{ }^{13} \mathrm{In}$ addition, the financial incentive to remain in theatre is stronger for some nonmilitary members than for military personnel.

Compared with nonmilitary members, military personnel may have had a higher rate of psychiatric diagnoses, and a lower return-to-duty rate after such diagnoses, for various reasons. For example, service members are ordered to

Table 4: Multivariable logistic regression analysis of factors associated with return to duty

\begin{tabular}{|lc|}
\hline Factor & Adjusted OR $(95 \% \mathrm{Cl}) *$ \\
\hline $\begin{array}{l}\text { Age (centred at } \\
\text { mean } 30.43 \mathrm{yr}), \text { per year } \\
\text { above the mean }\end{array}$ & $1.02(1.02-1.03)$ \\
\hline $\begin{array}{l}\text { Female sex } \\
\text { War-related injury }\end{array}$ & $1.91(1.78-2.06)$ \\
\hline Military status & $0.17(0.15-0.18)$ \\
\hline $\begin{array}{l}\text { Note: } \mathrm{Cl}=\text { confidence interval, OR = odds ratio. } \\
\text { *Adjusted for the variables listed in the table. }\end{array}$ \\
\hline
\end{tabular}

Table 3: Return-to-duty rates among evacuated nonmilitary and military personnel, by category of injury

\begin{tabular}{|c|c|c|c|c|c|}
\hline \multirow[b]{2}{*}{ Category of injury } & \multicolumn{2}{|c|}{ Nonmilitary personnel, no. (\%)* } & \multicolumn{2}{|c|}{ Military personnel, no. (\%)*† } & \multirow[b]{2}{*}{$p$ value $\neq$} \\
\hline & $\begin{array}{l}\text { Did not return } \\
\text { to duty } \\
n=1609\end{array}$ & $\begin{array}{l}\text { Returned } \\
\text { to duty } \\
n=546\end{array}$ & $\begin{array}{l}\text { Did not return } \\
\quad \text { to duty } \\
n=26330\end{array}$ & $\begin{array}{l}\text { Returned } \\
\text { to duty } \\
n=7675\end{array}$ & \\
\hline War-related injury & $527(95.6)$ & $24 \quad(4.4)$ & $10452(94.1)$ & $656 \quad(5.9)$ & 0.001 \\
\hline Combat-related§ & $296(97.0)$ & $9 \quad(3.0)$ & $4580(97.2)$ & $133 \quad(2.8)$ & 0.88 \\
\hline Psychiatric§ & $38(84.4)$ & $7(15.6)$ & $2822(90.8)$ & $286 \quad(9.2)$ & 0.003 \\
\hline Traumatic brain injury§ & $50(96.2)$ & $2 \quad(3.8)$ & $494(89.0)$ & $61(11.0)$ & 0.44 \\
\hline Musculoskeletal/spine** & $122(96.8)$ & $4 \quad(3.2)$ & $2104(96.7)$ & $71 \quad$ (3.3) & 0.65 \\
\hline Other** & $21(91.3)$ & $2(8.7)$ & $452(81.1)$ & $105(18.9)$ & 0.046 \\
\hline $\begin{array}{l}\text { Non-war-related injury } \\
\text { or disease }\end{array}$ & $1082(67.5)$ & $522(32.5)$ & $15878(69.3)$ & 7019 (30.7) & 0.001 \\
\hline Circulatory & $200(73.8)$ & $71(26.2)$ & $913(60.9)$ & $587(39.1)$ & $<0.001$ \\
\hline $\begin{array}{l}\text { Noncardiac chest or } \\
\text { abdominal pain }\end{array}$ & $135(56.0)$ & $106(44.0)$ & $597(48.1)$ & $645(51.9)$ & $<0.001$ \\
\hline Gastrointestinal & $131(64.5)$ & $72(35.5)$ & $1230(51.4)$ & $1165(48.6)$ & 0.21 \\
\hline Musculoskeletal/spine & $222(77.6)$ & $64(22.4)$ & $6984(84.1)$ & $1322(15.9)$ & 0.001 \\
\hline Other & $394(65.3)$ & $209(34.7)$ & $6154(65.1)$ & 3300 (34.9) & 0.031 \\
\hline $\begin{array}{l}\text { tData are from Cohen et al. } \\
\text { †For comparison between retur } \\
\text { \$All combat-related injuries, psy } \\
* * \text { Includes only injuries designa }\end{array}$ & $\begin{array}{l}\text { atric diagnoses a } \\
\text { to have occurred }\end{array}$ & $\begin{array}{l}\text { umatic brain in } \\
\text { g combat oper }\end{array}$ & $\begin{array}{l}\text { ry personnel. } \\
\text { s were considere }\end{array}$ & be war-related. & \\
\hline
\end{tabular}


war, whereas most nonmilitary personnel volunteer for hazardous duty assignments. Age is another factor: the nonmilitary members were older on average than the military personnel, which may translate to better coping skills and extensive support networks in the nonmilitary cohort. ${ }^{14-16}$ Another factor may be better screening for psychiatric conditions within the military hierarchy. ${ }^{14-16}$

In both groups, the proportion of personnel evacuated because of psychiatric diagnoses increased during the study period. This observation may reflect the more sophisticated screening instruments used over the course of the study, a lower threshold for diagnosis, and a decreased threshold for the manifestation of symptoms after repeated military operations. ${ }^{17,18}$ The adverse effect of psychopathology on return-towork after injury is consistent with findings in nonmilitary contexts. ${ }^{19,20}$

The last notable finding was the higher evacuation rate and lower return-to-duty rate among nonmilitary personnel versus military personnel with circulatory disorders and noncardiac chest pain, of which a substantial proportion were actually of cardiac origin. ${ }^{21}$ The most probable explanation for this finding is that the greater disease burden in this population was directly related to their higher mean age. ${ }^{22,23}$

\section{Limitations}

Our study has two main limitations. First, we report return-to-duty rates for nonmilitary members who were already evacuated out of theatre. Therefore, the true denominator for each diagnostic category remains unknown. Second, unlike the data presented for service members, ${ }^{3}$ which is estimated to contain data for more than $98 \%$ of US military evacuees, the data contained in the Deployed Warrior Medical Management Center is less inclusive for nonmilitary personnel. Among nonmilitary members, only US Department of Defense beneficiaries, who comprised $39.7 \%$ of our study population, receive routine non-emergency medical care outside of theatre. Because contractors are more likely than other nonmilitary members to experience war-related injuries, and life-threatening injuries are more likely than nonwar-related injuries to be treated at the trauma centre in Germany, these data may overestimate the extent of war-related injuries.

\section{Conclusion}

The reasons for medical evacuation among nonmilitary personnel were similar for the most part to those among military personnel. They were associated with higher incidence rates of disorders typically associated with older age, such as circulatory disorders and noncardiac chest or abdominal pain, and lower rates of other conditions (e.g., musculoskeletal/spine and psychiatric disorders). In addition, nonmilitary personnel were more likely than military personnel to be evacuated with non-war-related injuries but more likely to return to duty after such injuries. For evacuations because of war-related injuries, this trend was reversed. Because nonmilitary members are expected to play an increasingly prominent role in future military operations, recognizing the types of medical conditions they experience may be useful in implementing preventive measures and treatment strategies.

\section{References}

1. Hoeffler DF, Melton LJ. Changes in the distribution of Navy and Marine Corps casualties from World War I through the Vietnam conflict. Mil Med 1981;146:776-9.

2. Writer JV, DeFraites RF, Keep LW. Non-battle injury casualties during the Persian Gulf War and other deployments. Am J Prev Med 2000;18(3S):64-70.

3. Cohen SP, Brown C, Kurihara C, et al. Diagnoses and factors associated with medical evacuation and return to duty for service members participating in Operation Iraqi Freedom or Operation Enduring Freedom. A prospective cohort study. Lancet 2010;375:301-9.

4. Cole A. Afghanistan contractors outnumber troops. Wall Street Journal [New York] 2009 Aug 22;Sect A:6. Available: http: //online.wsj.com/article/SB 125089638739950599.html (accessed 2010 Nov. 5).

5. Glanz J. Contractors outnumber U.S. troops in Afghanistan. New York Times 2009 Sept 2;Sect A:10. Available: www.nytimes .com/2009/09/02/world/asia/02contractors.html?_r=1 (accessed 2010 Nov. 5)

6. Valat JP, Goupille P, Védere V. Low back pain: predictors of chronicity. Rev Rhum Engl Ed 1997;64:189-94.

7. Danchin N, David P, Robert P, et al. Employment following aortocoronary bypass surgery in young patients. Cardiology 1982;69:52-9

8. Molton IR, Stoelb BL, Jensen MP, et al. Psychosocial factors and adjustment to chronic pain in spinal cord injury: replication and cross-validation. J Rehabil Res Dev 2009;46:31-42.

9. Noble J, Gomez M, Fish JS. Quality of life and return to work following electrical burns. Burns 2006;32:159-64.

10. Cohen SP, Argoff CE, Carragee EJ. Management of low back pain. BMJ 2008;337:a2718.

11. Belmont PJ, Schoenfeld AJ, Goodman G. Epidemiology of combat wounds in Operation Iraqi Freedom and Operation Enduring Freedom: orthopaedic burden of disease. J Surg Orthop Adv 2010;19:2-7.

12. Taanila H, Suni J, Pihlajamäki H, et al. Musculoskeletal disorders in physically active conscripts: a one-year follow-up study in the Finnish Defence Forces. BMC Musculoskelet Disord 2009;10:89.

13. Knapik JJ, Reynolds KL, Harman E. Soldier load carriage: historical, physiological, biomechanical, and medical aspects. Mil Med 2004;169:45-56.

14. Masho SW, Ahmed G. Age at sexual assault and posttraumatic stress disorder among women: prevalence, correlates, and implications for prevention. J Womens Health (Larchmt) 2007;16:262-71.

15. Yum BS, Roh JH, Ryu JC, et al. Symptoms of PTSD according to individual and work environment characteristics of Korean railroad drivers with experience of person-under-train accidents. J Psychosom Res 2006;61:691-7.

16. Averill PM, Beck JG. Posttraumatic stress disorder in older adults: a conceptual review. J Anxiety Disord 2000;14:133-56.

17. Reger MA, Gahm GA, Swanson RD, et al. Association between number of deployments to Iraq and mental health screening outcomes in U.S. Army soldiers. J Clin Psychiatry 2009;70:1266-72.

18. Kline A, Falca-Dodson M, Sussner B, et al. Effects of repeated deployment to Iraq and Afghanistan on the health of New Jersey Army National Guard troops: implications for military readiness. Am J Public Health 2010;100:276-83.

19. Krause N, Frank JW, Dasinger LK, et al. Determinants of duration of disability and return-to-work after work-related injury and illness: challenges for future research. Am J Ind Med 2001;40:464-84. 
20. Fadyl JK, McPherson KM, Schlüter PJ, et al. Factors contributing to work-ability for injured workers: literature review and comparison with available measures. Disabil Rehabil 2010;32:1173-83.

21. Cohen SP, Kapoor S, Anderson-Barnes VC, et al. Non-cardiac chest pain during war. Clin J Pain 2011;27:19-26.

22. Fass R, Dickman R. Non-cardiac chest pain: an update. Neurogastroenterol Motil 2006;18:408-17.

23. Tu JV, Nardi L, Fang J, et al.; Canadian Cardiovascular Outcomes Research Team. National trends in rates of death and hospital admissions related to acute myocardial infarction, heart failure and stroke, 1994-2004. CMAJ 2009;180:E118-25.

Affiliations: From the Department of Anesthesiology (Cohen, Brown), Johns Hopkins School of Medicine, Baltimore, Md.; the Department of Surgery, Anesthesia Service (Cohen, Kurihara), Walter Reed Army Medical Center, Washington, DC; the Department of Surgery (Plunkett), 31st Combat Support Hospital, Camp Dwyer, Afghanistan; the Department of Surgery (Nguyen), Landstuhl Regional Medical Center, Landstuhl, Germany; and the Division of Pharmacy Practice (Strassels), University of Texas at Austin, Austin, Tex.
Contributors: Steven Cohen and Scott Strassels were responsible for the study concept and design. Steven Cohen, Charlie Brown, Connie Kurihara, Conner Nguyen and Anthony Plunkett were responsible for categorizing and organizing the data. Scott Strassels performed the statistical analysis. Steven Cohen and Scott Strassels wrote the manuscript. All of the authors revised it critically for intellectual content and approved the final version submitted for publication.

Funding: This study was funded in part by a congressional grant from the John P. Murtha Neuroscience and Pain Institute, the US Army and the Army Regional Anesthesia and Pain Medicine Initiative.

Acknowledgement: The authors thank Ms. Annie Ho, Defense Manpower Data Center, Monterey, Calif., for her help with categorizing personnel.

The opinions and assertions contained herein are the views of the authors and are not to be construed as official or as reflecting the views of the US Department of the Army or the US Department of Defense. 